Article

\title{
On the Fringes of Urban Justice: Violence and Environmental Risks in Guatemala City
}

\author{
Florencia Quesada \\ Department of Cultures, University of Helsinki, Finland; florencia.quesada@helsinki.fi
}

Submitted: 28 July 2021 | Accepted: 1 November 2021 | Published: 25 January 2022

\begin{abstract}
Living in the city's ravines is the common destiny of thousands of poor urban dwellers in Guatemala City, as is too often the case elsewhere in the Global South. The ravines surrounding the city represent one of the most visible and unjust urban spaces in the nation's capital. At the same time, Guatemala City has been among the most violent cities in the world and is highly vulnerable to climate change. Employing a critical spatial perspective and drawing on interviews in two at-risk communities-Arzú and 5 de Noviembre-this article examines the social production of such peripheral spaces. The levels of exclusion and inequalities are analysed by focusing on the multiple manifestations (visible and invisible) of violence and environmental risks, and deciphering the complex dynamics of both issues, which in turn generate more unequal and harmful conditions for residents. This article draws on the theoretical ideas elaborated by Edward Soja, Mustafa Dikeç, and Teresa Caldeira on the contextualisation of spatial injustice and peripheral urbanisation to study the specific conditions of urban life and analyse the collective struggles of people in both communities to improve their current living conditions and mitigate the risk and the precariousness of their existence. The article underlines the need to make the processes of urban exclusion and extreme inequality visible to better understand how they have been socially and politically constructed. The research argues for more socially and ecologically inclusive cities within the process of unequal urbanisation.
\end{abstract}

\section{Keywords}

environmental risks; exclusion; Guatemala City; insecurity; precarious settlements; spatial injustice; urban segregation; violence

\section{Issue}

This article is part of the issue "Recent Trends in Inequality and Exclusion in Latin America" edited by Maria Amparo Cruz Saco (Connecticut College / Universidad del Pacífico).

(C) 2022 by the author(s); licensee Cogitatio (Lisbon, Portugal). This article is licensed under a Creative Commons Attribution 4.0 International License (CC BY).

\section{Introduction}

Latin American cities are the prime domains of inequalities and violence deeply related to social and economic exclusion (Briceño-León \& Zubillaga, 2002; Koonings \& Kruijt, 2007, 2009, 2015; Moser \& Mcllwaine, 2004; Muggah \& Aguirre, 2018; Roberts, 2010). The fear and insecurity associated with high levels of violence are the "daily bread" of millions of urban dwellers. In recent decades, the countries in the northern part of Central America (Guatemala, El Salvador, and Honduras) have had the highest homicidal and criminal violence rates in the world (Bruneau et al., 2011); but violence is not a new phenomenon in any of these countries, where extremely insecure urban spaces are a direct consequence of the intersection and overlapping of several path-dependent and structural causes (Bourgois, 2015; González-Isás, 2017; Huhn \& Warnecke-Berger, 2017; Kurtenbach, 2013; Rodgers, 2009).

Guatemala has had a long history of violence and state repression by authoritarian regimes, including a prolonged and genocidal civil war spanning 36 years and a very violent post-conflict society (Carey \& Torres, 2010; Grandin, 2000; Sanford, 2008; Torres-Rivas, 2007). Consequently, one important dimension of the social insecurities of Guatemalans today is a by-product of the legacies of armed conflict. Guatemala City, both a postconflict and a fragile city (Muggah, 2014), is a capital 
where multiple types of violence (visible and invisible) overlap and come together in relation to the long history of authoritarianism, political violence, and socioeconomic and ethnic exclusion (O'Neill \& Thomas, 2011). Old and new expressions of violence metamorphose, intersect, and overlap, generating new forms and more complex expressions of violence (Camus et al., 2015; Moser \& Mcllwaine, 2004; Winton, 2004, 2005).

Violence has been normalised, perceived as a central, endemic, and inevitable part of society (Koonings \& Kruijt, 2007; Moser \& Mcllwaine, 2014). Conflict and violence are strongly associated with a high incidence of urban insecurity and fear, a multidimensional and manifold phenomenon affecting all sectors of society, but especially critical for poor urban areas (Mcllwaine $\&$ Moser, 2007). As prior research indicates, social exclusion and inequality are the main drivers of interpersonal violence in Central American urban spaces (Pérez-Sáinz, 2015, 2018; Winton, 2004).

Simultaneously, the Central American region is highly vulnerable to the effects of global climate change and prone to natural hazards, such as earthquakes, hurricanes, tropical storms, droughts, and volcanic eruptions (Montero \& Peraldo, 2004). Historically, squatting in areas vulnerable to natural hazards, such as the ravines (barrancos) of Guatemala City, has been the only accessible option for the poor urban classes (Gellert, 1996; Miles et al., 2012; Morán, 2011; Platas et al., 2016).

This article aims to understand the spatial production of injustice in Guatemala City. I examine the structural dynamics that produce and reproduce injustice through space (Caldeira, 2017; Dikeç, 2001; Soja, 2010), focusing on the multiple manifestations of violence and environmental hazards and vulnerabilities in two "precarious settlements" (the term used in Central America). Based on qualitative research in the communities of Arzú and 5 de Noviembre, the article explores the complex spatial dynamics that create geographies of exclusion and fear, as exhibited in the extreme urban segregation and socio-economic and spatial marginalisation of ravine dwellers.

I pay particular attention to the residents' perceptions of risks, vulnerabilities, and fears, and the impact they have on their everyday life, their well-being, and their social relations. Typically, urban violence and environmental risks have been examined separately. This article examines them together, assessing environmental risks through the lens of structural violence (Farmer, 2003; Galtung, 1969). I argue that residents in both communities are exposed to and trapped by multiple forms of exclusion, types of risks, and manifestations of violence at all levels. Emphasising the spatiality of injustice highlights the dynamics of marginalisation and injustice (Dikeç, 2001).

Violence and environmental risks in Latin America are seldom examined together with a critical spatial perspective. The present article contributes to the existing literature on socio-spatial segregation in Latin America and provides a deeper understanding of the dynamics of extreme urban and social exclusion.

\section{Spatial Justice: The Injustice of Spatiality, Structural Violence, and Peripheral Urbanisation}

Drawing on Soja (2009, p. 2), this article defines the concept of spatial (in)justice as "an intentional and focused emphasis on the spatial or geographical aspects of justice and injustice," noting that, "as a starting point, this involves the fair and equitable distribution in space of socially valued resources and the opportunities to use them." Space is socially produced; consequently, it can be changed. Thus, characterising spatial injustice becomes a matter of analysing and locating it in a specific urban context-in this case, the analysis of two at-risk communities in the ravines-to contextualise how the unjust urban geographies of Guatemala City have been historically and socially created (Soja, 2010, p. 32).

Moreover, as Dikeç (2001, p. 1797) proposes, a better understanding and conceptualisation of the relationship between space and injustice requires focusing on the structural dynamics that produce and reproduce injustice through space. The distinction between the spatiality of injustice and the injustice of spatiality is essential in this process. The difference between them is that the former presupposes that justice has a spatial dimension, meaning that we can examine different forms of injustice in space (Dikeç, 2001, p. 1792). The injustice of spatiality, on the other hand, examines the structural dynamics and processes that contribute to the creation of such segregated spaces. Dikeç (2001, p. 1799) elaborates further on the differences and relationship between both concepts:

The interplay between the two-spatiality of injustice and the injustice of spatiality-is important as it implies that although the spatiality of injustice may be captured as a snapshot, so to speak, of spatial practices (for example, segregated neighborhoods, public transportation network, the dominated city center, etc.), the policies and actions conceived to address the issue should take into consideration the structural dynamics of spatialization (for example, the organization of property markets, housing, rent, and tax policies, etc.), which the notion of the injustice of spatiality tries to capture.

Hence, an emphasis on the injustice of spatiality provides the tools necessary to examine how such exclusion and injustice are produced. Without a critical spatial perspective, the creation and consolidation of these types of marginal spaces will likely remain invisible (Soja, 2010, p. 42). Thus, it is essential to make visible the discriminatory processes and geographies and acknowledge the production of such spaces as historically, socially and politically constructed rather than naturally determined (Soja, 2010, p. 48). 
Simultaneously, the injustice of spatiality is addressed through the concept of "structural violence" (Farmer, 2003; Galtung, 1969). The term, coined by Galtung (1969, p. 171), asserts that "violence is built into the structure and shows up as unequal power and consequently as unequal life chances." Structural violence is embedded in the political, economic, and social system of a state, reproducing structures of inequality and exclusion; it is closely linked to suffering and social injustice. When people are denied access to health services, a good education, and jobs, when they are forced to live in vulnerable and risky spaces that are also insecure and violent, we should identify these conditions as structural violence (Farmer, 2003; Galtung, 1969).

Inequality is the most important form of structural violence. Inequality can trigger everyday conflict, crime, or general incidents of violence (Winton, 2004, p. 166). Paul Farmer, building on Galtung, has further developed the concept of structural violence based on his experience as a medical anthropologist and physician in Latin America. He notes that structures of violence are the outcome of lengthy political and economic struggles and processes, the result of forms of injustice and adversity embedded within the system (Farmer, 2003). Significantly, factors related to age, gender, and ethnicity strongly contribute to the vulnerability and suffering of certain social groups. But this condition does not in and of itself explain the causes of people's suffering or vulnerability. To discover the root causes of inequality, it is essential to analyse the processes that produce structural violence on a deeper level (Farmer, 2003, p. 50).

This study also draws on Caldeira's (2017) peripheral urbanisation ideas. Her approach provides the essential tools for analysing the dynamics of how marginal areas are produced in cities in the Global South, where the modes of urbanisation are different than in the Global North. Caldeira (2017, p. 5) de-centres urban theory, an essential step to understanding the specific forms of agency and temporalities in the Global South. In Guatemala City, poor urban dwellers are forced to claim a space in which to live and build their houses in the margins of the city through transversal interactions with the state and other institutions. Caldeira offers a general characterisation of those processes when re-examining and deciphering the logics of peripheral spaces in producing highly unequal and heterogenous cities in the Global South. The transversal logics angle does away with the traditional binary and simple dualistic opposition of formal/informal or legal/illegal when accounting for complex urban formations (Caldeira, 2017, p. 7). To unpack these dynamics, an analysis over time is fundamental to drawing out the simultaneous processes of improvement and reproduction of inequalities, and therefore, of injustice.

In drawing on these theoretical approaches, this article examines the social production of peripheral spaces by focusing on the multiple manifestations of violence and environmental risks while untangling the complex dynamics of both issues and how they generate unequal and harmful conditions for residents, thereby intensifying and reproducing inequalities.

\section{Qualitative Research Methods in Violent Settings}

This article draws on fieldwork conducted in Guatemala City in January and February 2018. It uses a qualitative approach with the support of Perpendicular, a Guatemalan social innovation laboratory that served as a key collaborator. Perpendicular worked in both communities in 2017, creating a participatory digital mapping illustration of the risks. Through their contacts, interviews were arranged with the leaders and other members of the community.

Conducting qualitative research in highly violent settings is both risky and challenging. It requires being flexible and having a clear understanding of the environment and the possible dangers for both the researcher and the interviewees. Thanks to previous work done by members of Perpendicular in the community and the trust they have gained, the fieldwork was successful. On the other hand, I was surprised as to how little I was myself prepared as a researcher to face the possible risks encountered in the field, and how this is seldom or openly discussed in academia (Goldstein, 2014).

Violence is a difficult and highly sensitive topic to talk about, and people are normally reluctant to discuss it openly. As a measure of protection and security for both the interviewees and ourselves, the interviews were always conducted inside the houses of selected members of the community, individually, and without the presence of any other members of the family in the room (Bashir, 2018). For the same reason, the residents interviewed will remain anonymous. Conducting interviews in a resident's home was another methodological opportunity to both observe and experience first-hand their living conditions and needs (Bashir, 2018, p. 640).

The fieldwork included 25 formal, in-depth, semistructured interviews with residents of 5 de Noviembre (13) and Arzú (12). Semi-structured interviews are more appropriate in such contexts because they give the person more flexibility and space to choose whether or not to respond or share sensitive issues. To achieve a wide range of perspectives by gender and age, we interviewed 11 adult women, three of whom had teenage daughters, and seven adult men, two of whom had teenage sons and two younger boys. The focus of the interviews was on their perceptions of vulnerabilities and fears related to urban violence and environmental risks. However, many other types of violent and traumatic experiences emerged during the in-depth interviews. In addition, I consulted authorities from the municipality in zone 18 and other NGOs, such as Youth Against Violence, TECHO, and Innovaterra. Additionally, I draw on the results from the participatory digital mapping work done by Perpendicular to complement the information obtained through fieldwork. 
It is impossible to ascertain a resident's perceptions of vulnerabilities and risks based on general surveys. Hence, conducting in-depth interviews in peripheral urban spaces is a unique way to examine a resident's daily life, experiences, and conflicts. I used inductive methods to assess the transcripts, mainly through thematic content analysis, while identifying common topics to discover general patterns in the data and assessing such patterns via my research questions and theoretical approach.

\section{Precarious Settlements in the Ravines}

Guatemala City, the largest capital city in Central America, is a city of great contrasts: It suffers from high levels of income inequality and extreme social-spatial segregation, resulting in urban exclusion (Ayala, 2014; Morán, 2011). According to the most recent census, the municipio of Guatemala-which is mainly urban-has an estimated population of 923,392 (National Institute of Statistics of Guatemala, 2018). Simultaneously, the metropolitan area accounts for the largest concentration of poor people per square metre in the country, with an estimated 412 precarious settlements (Secretariat for the Planning and Programming of the Presidency, 2015; see Figure 1). It is hardly surprising then that these "invisible inhabitants" were only included in the official statistics of the country for the first time in the last census (National Institute of Statistics of Guatemala, 2018).

For the poor urban classes who cannot afford adequate housing, squatting in risk-prone areas vulnerable to natural hazards has been their only option for decades, the best expression of the geographies of injustice so evident in the capital. Such is the case with the ravines surrounding the city, which comprise 42 percent of Guatemala City's territory (Mazariegos et al., 2014). The municipality of Guatemala is divided into 22 zones, with the greatest number of precarious settlements being in zones 3, 7, and 18 (Secretariat for the Planning and Programming of the Presidency, 2015). Zone 18 is the largest and most populous area in the northern part of the city. It is also considered the most violent and dangerous of the 22 zones in the capital.

During the massive 1976 earthquake in Guatemala $(M=7.6)$, those living in precarious settlements in the metropolitan area suffered the highest mortality rate (Gellert, 1996, p. 35; Miles et al., 2012, p. 368). The earthquake also marked a period of intensive rural-urban migration, exacerbated by years of civil war and genocide directed at the Maya population. Many survivors

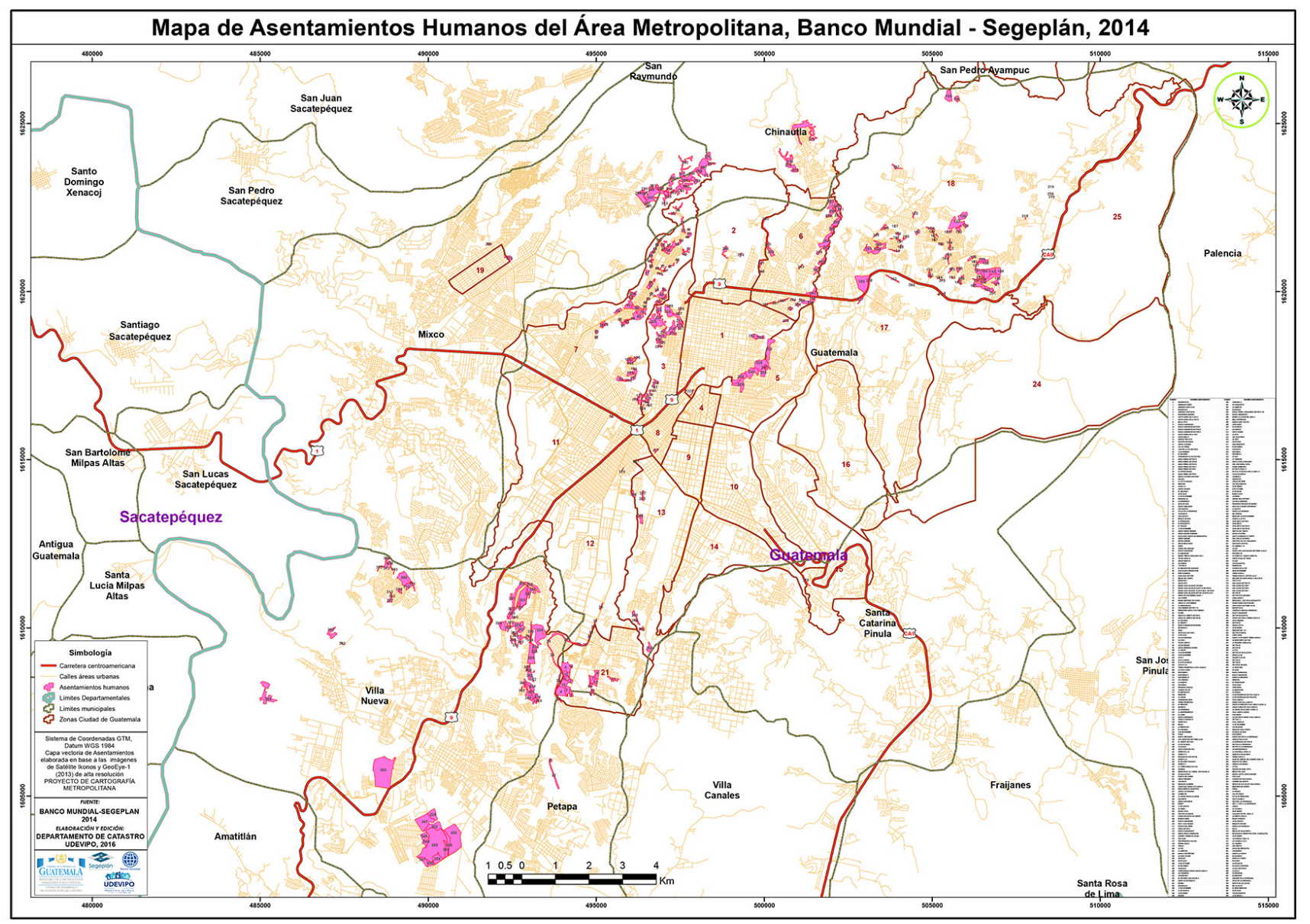

Figure 1. Map of precarious settlements in the metropolitan area of Guatemala City in 2014. Source: Secretariat for the Planning and Programming of the Presidency (2015). 
from rural areas seeking to escape the violence and find new opportunities moved to Guatemala City, resulting in some of the more precarious settlements in the ravines (Morán, 2011, p. 46).

The communities examined in this article are situated in the ravines in zone 18 (see Figures 2 and 3). Arzú started to grow in 1995, while 5 de Noviembre was founded in a garbage dump in 2003. Both communities are characterised by self-built housing with limited and inadequate public services and infrastructure. The older areas in the upper parts of the ravine have better housing infrastructure than the newer ones. The communities are not homogenously poor and precarious since they are always changing, being transformed and sometimes improving (Díaz et al., 2000; Morán, 2011; Perpendicular, 2017a, 2017b; Roberts, 2010).

Housing, public infrastructure, and other services have improved over time thanks to community organisation and help from the municipality and the state, but especially through the support of NGOs such as TECHO. TECHO is a Latin American and Caribbean youthled NGO seeking to eradicate poverty in popular settlements through the joint actions of residents and young volunteers. However, such improvements have always occurred from a marginal and excluded position. One of the major improvements is linked to the legalisation of the plots-contesting the official logic in transversal ways, as Caldeira (2017, p. 7) argues; a high percentage

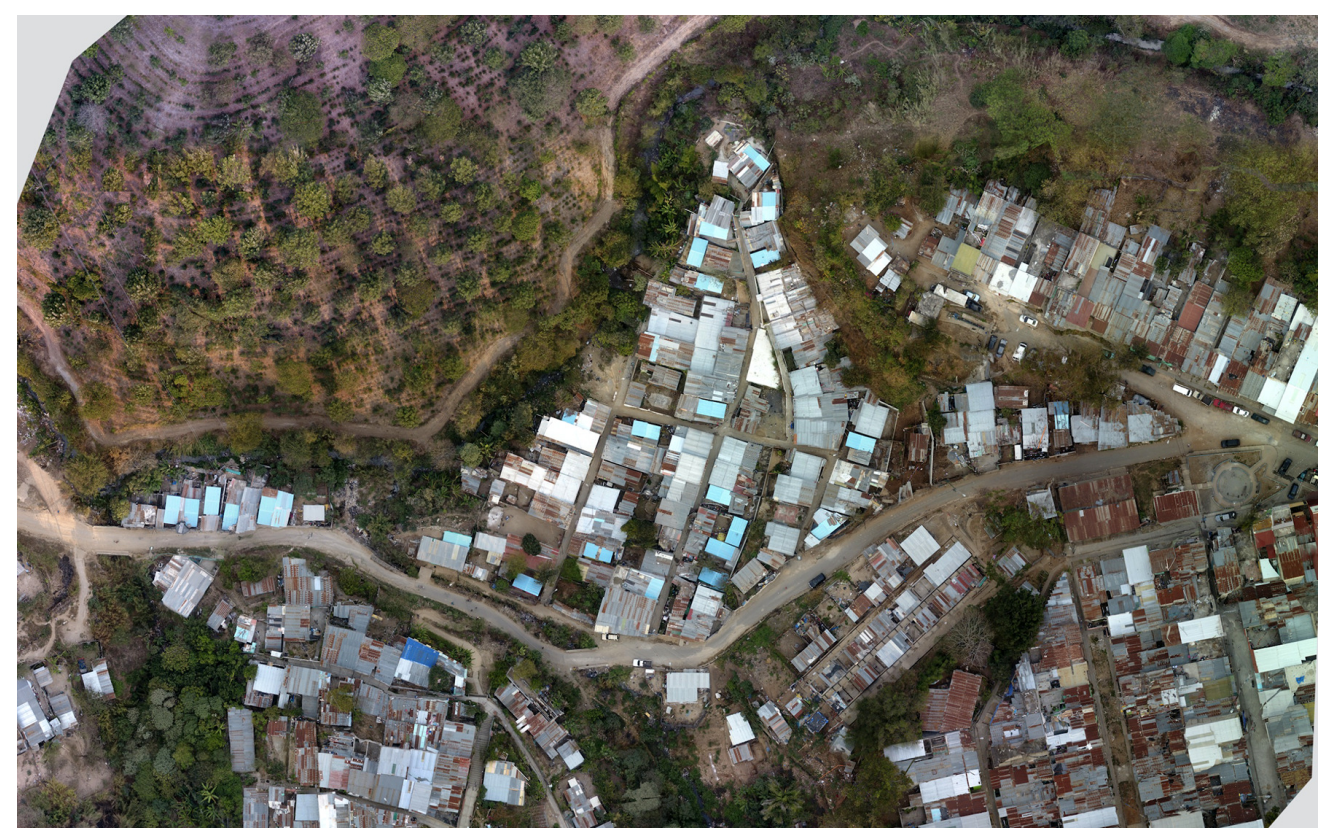

Figure 2. Orthophoto of 5 de Noviembre, courtesy of Perpendicular.

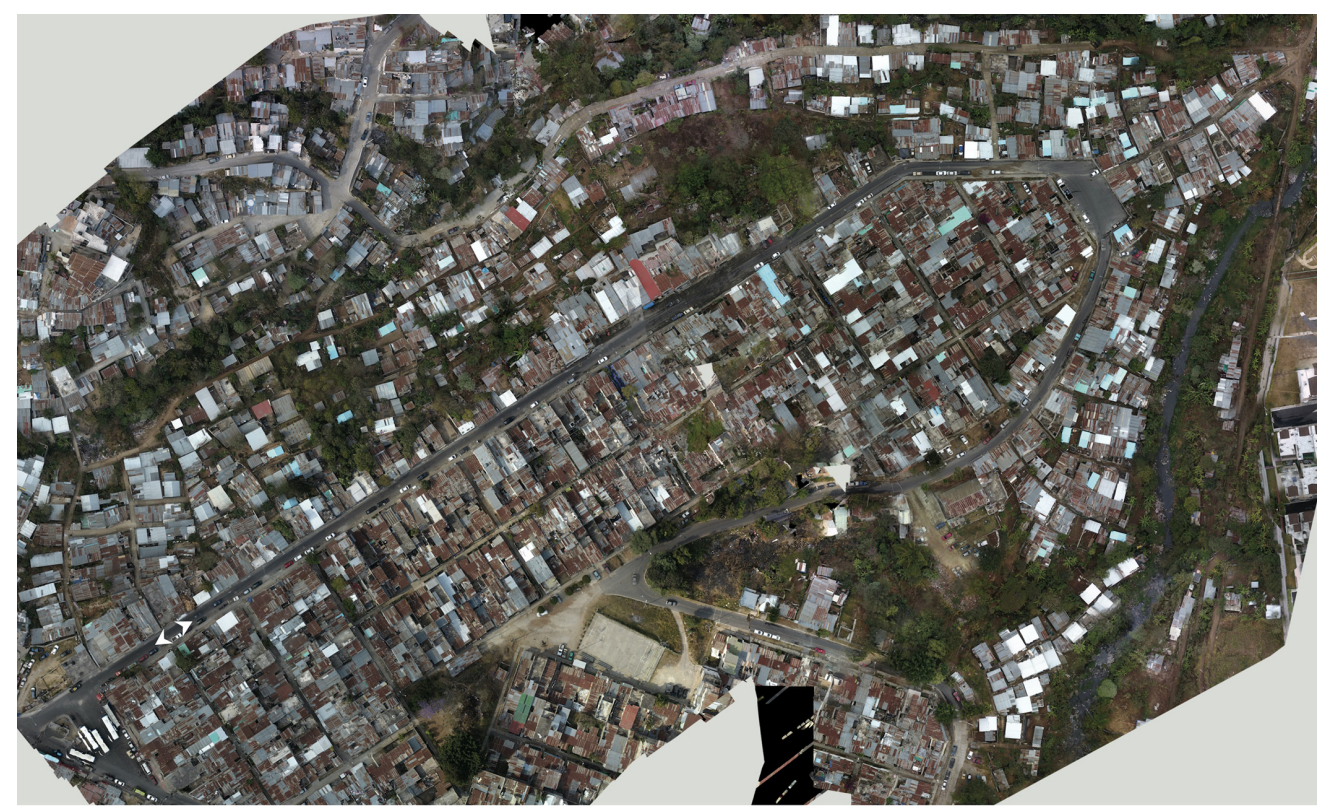

Figure 3. Orthophoto of Arzú, courtesy of Perpendicular. 
of the residents have been able to reclaim land titles for properties located in high-risk areas, where, supposedly, land titles would not have to be granted. In 5 de Noviembre, 54 percent of the lots have been legalised, and the same is true of 70 percent of the 329 existing lots in Arzú (Perpendicular, 2017a, 2017b). Simultaneously, urban marginality is expressed by the limited formal opportunities for employment, education, and access to health services.

\section{5. "A Stray Bullet": Perceptions of Risks and Threats of Violence in Peripheral Urban Spaces}

Violence is a disputed, complex, and "slippery" concept that is difficult to define (Moser, 2004; ScheperHughes \& Bourgois, 2004). Even though it is impossible to develop strict typologies for the multiple manifestations of violence, the present article adopts the conceptual framework proposed by Moser (2004), who identifies four types of violence: political, institutional, economic, and social violence. Political violence is associated with both state and non-state violence (e.g., political assassinations); institutional violence is associated with the state and other "informal institutions" (e.g., extrajudicial killings, physical or psychological abuse by health and education workers, the lynching of criminals by community members); economic violence can take the form of, for instance, street theft, armed robbery, drug trafficking, assaults, killings, and rape occurring during the course of committing economic crimes; finally, social violence can take the form of domestic violence, sexual (rape) violence, child abuse, and general incivilities, such as instances of road rage or street confrontations (Moser, 2004, pp. 4-5). Within this broad typology, many other overlapping types of violence can also be identified in the everyday lives of the residents of such peripheral communities, including structural violence.

Residents in both communities reported an overwhelming fear of violence, and hence, they constantly feel at risk and a sense of insecurity in their everyday lives. These perceptions of violence, as well as actual manifestations of it, take place in their homes, inside, and outside the community, and in other parts of the city. Many residents expressed a general sense of pessimism, saying that "violence is everywhere," "the violence will never end," and elaborated that "regarding the maras [gangs], we are lost, they are bad for your health." One middleaged man from Arzú added the following observation:

Wherever you go into the city, it is dangerous; I don't know why [just this place] here is characterised as a "red zone." If we talk about red zones, all the colonias and other parts of the city are also dangerous.

The most typical type of insecurity is the fear of being a victim of a "stray bullet" in the streets, whether by the maras or by any of the diverse array of violent actors and ordinary criminals found on the streets (Camus et al.,
2015; Winton, 2004, p. 138). The easy availability of firearms and the rampant levels of impunity and corruption are especially reflected in such urban spaces (Levenson, 2013).

The following is a list of risks and insecurities related to violence in both Arzú and 5 de Noviembre, according to community interviews:

- Maras and gangs/shootings "stray bullet";

- Extortion;

- Rapes;

- Homicides;

- Robberies/house burglaries;

- Domestic violence;

- Verbal and physical violence among neighbours (gossip, insults, fistfights, alcoholism, drug use);

- Violence on the streets (fights);

- Police abuse (insults);

- Insecurity, red public buses (extortion, murders, robberies);

- Forced recruitment of minors to join the maras;

- Harassment and intimidation by the maras (young boys and girls);

- High-speed cars and motorcycles, accidents on the main streets.

The informants noted that the maras (18 and Salvatrucha) and other minor gangs are the most "visible" problem in terms of insecurity, as they are considered the main protagonists of violence (Bruneau et al., 2011; Levenson, 2013; Winton, 2005; Wolf, 2017). In both communities, the maras control the nearby surroundings; physically they are quite present (see Figure 4). Their battles for control of the drug market and territory regularly involve shootings, which profoundly impacts the daily lives of the residents of these communities, especially during the night, "when the maras reign," considered the most dangerous time of the day (Jütersonke et al., 2009).

Some groups or individuals are more at risk from certain types of violence than others (Moser \& Mcllwaine, 2014 , p. 335; Winton, 2004, p. 166). For example, young boys (and their families) are afraid of being victims of the forced recruitment of minors to join the gangs. This was the case with a blacksmith in his late 30s in Arzú. He had been shot by a member of 18 , the gang that rules the area, a few years ago. The gang member came to recruit his young cousin by force, who was working in the man's workshop at the time. His cousin escaped, but he himself was not so fortunate. The young marero faced him and began shooting without mercy: Four bullets hit him in the arms (two in each). While trying to escape, a final bullet hit him in the spinal cord-and it is still there. He can no longer walk and is condemned to live in a wheelchair. Now his life is limited to a $5 \times 5$ space; he is disabled, suffers from diabetes, and does not receive any support or economic aid from the state. His options are quite limited. His extended family-parents, wife, and two adult 


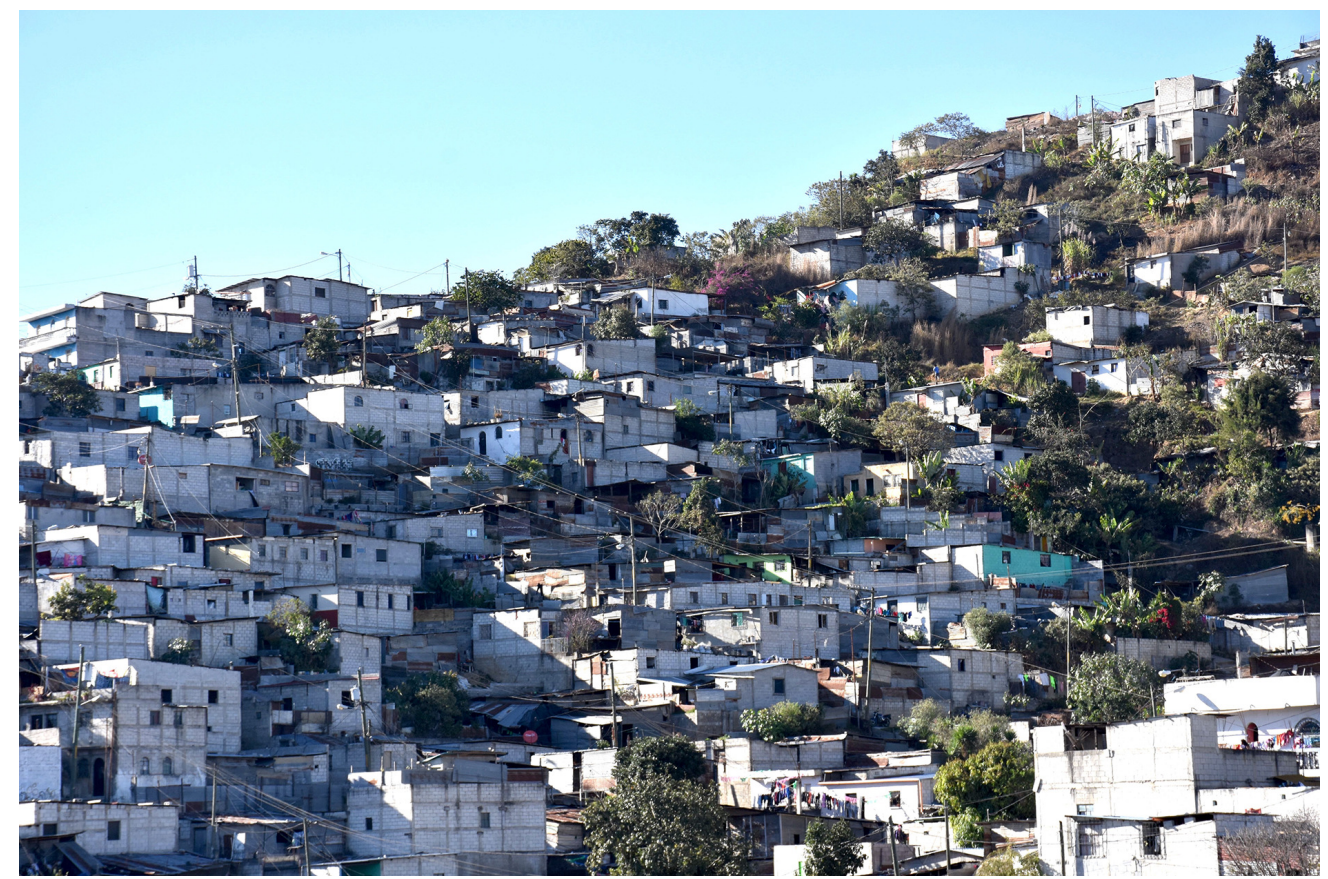

Figure 4. The community in front of Arzú, some parts of which are controlled by gangs.

sons-are his only means of support. He seldom leaves the house, as the logistics of climbing the steep hill where he lives are complex. Structural violence overlaps in the life of this man with other types of violence, whether direct, indirect, visible, or invisible, in the crude realities of the injustice of spatiality.

Younger boys are also afraid of older maras in the streets because the gang members repeatedly bully and harass them in the form of verbal or physical abuse. Eventually, the youngsters also begin imitating certain practices of the maras. During our fieldwork, one of the boys from the community "jokingly" painted some graffiti with the message "soccer field MS 13" (see Figure 5). He reproduced the same symbolic signs of power used by the maras in the territories controlled by them in his community and the only precarious public space frequented mainly by boys.

For women in general, and younger women in particular, the maras and other gangs represent a constant threat, as expressed by one young female resident from 5 de Noviembre, aged 12:

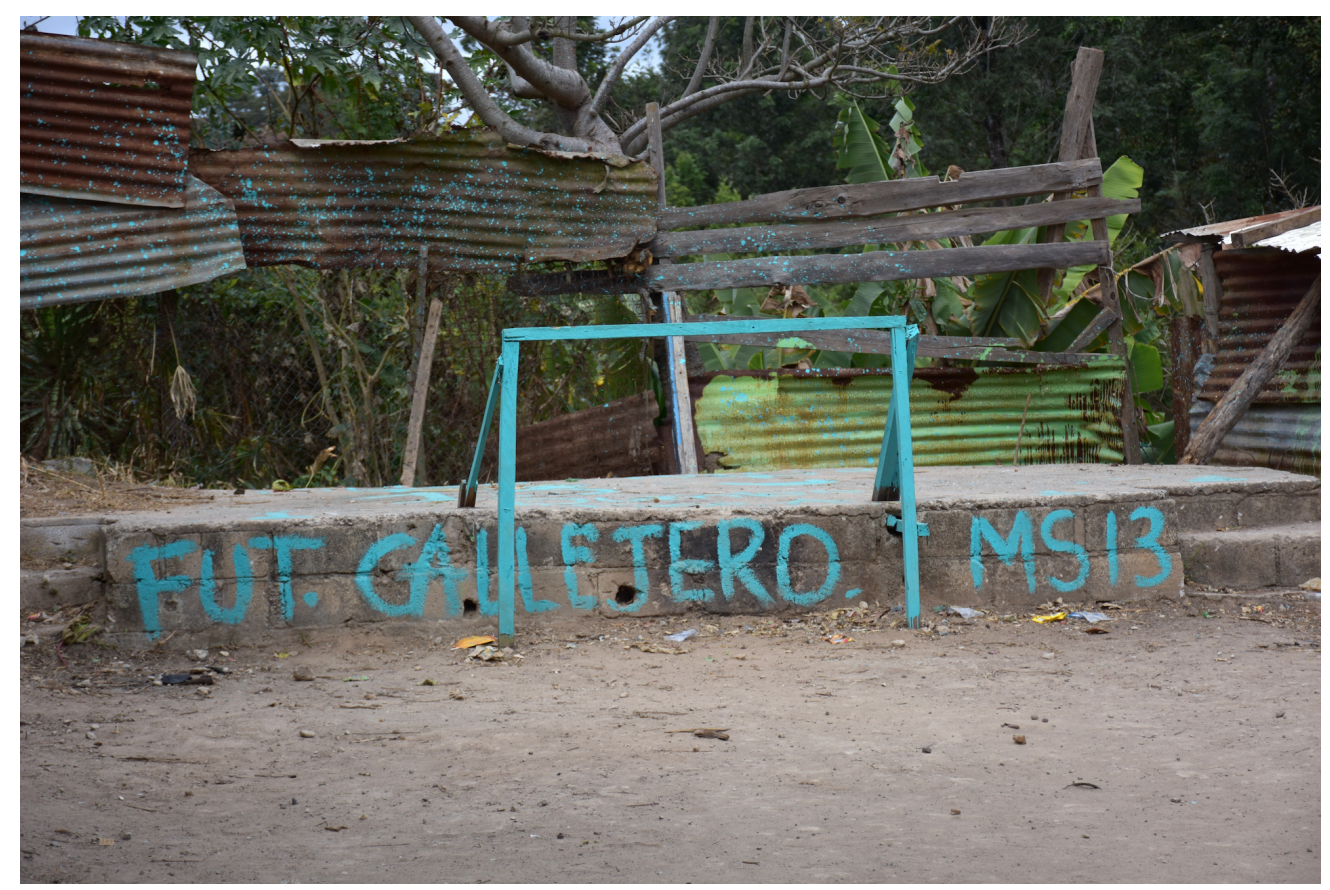

Figure 5. Soccer field in 5 de Noviembre. 
I am afraid because there are a lot of gangs and [because of] all the things that have happened. Sometimes I tremble and I can't walk fast [enough], and it's when I should walk faster, so I won't show them I am afraid. Otherwise, they can harm you or threaten [that] you [need] to be their "friends."

On the other hand, some residents also expressed compassion for the maras, acknowledging that they are the product of social exclusion and a lack of opportunities, "without parents, resources and raised on the streets" (see Snodgrass-Godoy, 1999). In the absence of the state, the maras can also become allies or protectors of the community (Koonings \& Kruijt, 2009, p. 20; Winton, 2004). As is the case in 5 de Noviembre, many were literally born and raised in a garbage dump in the ravine. Back in 2003, a squatter nicknamed Colocho, the leader of a local mara faction, took over the terrain with the support of the National Coordination of Marginalized Communities and Areas of Guatemala (CONAPAMG). The terrain was subdivided after a complex process of negotiations between the leader and the squatters. A middle-aged woman who was one of those original squatters offered the following recollection:

I heard from a woman that somebody was giving away lots. So, I came; it was a garbage dump here. I asked a group of people if they were giving out lots. A man said to me: "Look, if you want a lot, nobody is giving it for free; you have to come and fight for it. And if you are brave enough to fight, you must come and stay, day and night, taking care of your space, rain or shine".... came with my newborn baby because I was in need.

Colocho was the guiding power in the community for ten years. The residents of 5 de Noviembre paid him a monthly fee in exchange for protection. Some basic services were introduced and built under his guidance. He organised the division of labour and forced the residents to help construct and improve the infrastructure and collect garbage (sometimes in coercive and violent ways). He also organised social activities on special occasions (Mother's Day, Children's Day). Until his death, as the result of a territorial dispute, Colocho oversaw the organisation, security, and protection of the community. Residents mentioned, with mixed and controversial feelings, how well organised the area had been under his rule, despite his authoritarian and intimidating practices. A level of "organisation" is currently absent in the community. As Moser (2004, p. 171) notes, "the drug faction is given anonymity and freedom to conduct business, and the community in return receives internal security and often a range of services."

Gender-based violence is present in both communities, less "visible" and not as openly discussed as other types of violence. For young women, especially teenagers, their greatest fear and insecurity is sex- ual assault, which affects their freedom and mobility. The feeling of fear in a certain space is socially constructed and conditioned by various gendered power relations (Winton, 2004). Consider as an example the story of a 23-year-old single mother raped at her daycare when she was around five years old:

The son of the lady who was running the daycare raped the girls. He was sent to jail, but now he is out. He raped me when I was little. My mother told me she found blood in my clothes and took me to the doctor. The doctor told my mom that she should immediately get me out of there. I vaguely remember him asking me if I wanted this or that. But when you are a child, you don't know what is good or bad. Now, the father of my daughter-he is very machista [sexist]; he wanted me to be a virgin when we got together. But since I was not, because I was raped when I was little, he left me. I didn't know I was pregnant when he left me. That is why I am a single mother now: Because he wanted me to be a virgin.

Her traumatic experience shows the suffering of women abused throughout their lives in a succession of different and toxic types of violent acts, both outside and inside the home, and deeply embedded in the macho culture (Hume, 2004). In public spaces, mothers are particularly worried about the safety of their daughters, protecting and controlling their movements most of the time. Another woman from 5 de Noviembre shared with us another painful experience involving her only daughter: "About five years ago, a man attempted to rape my 8 -year-old daughter. I was living in a champita [metal zinc house] down there. It was my neighbour." Some families are forced to share a communal shower: A dangerous space where young girls are at risk of being raped.

Women in Guatemala are especially vulnerable to sexual violence, with the country having one of the highest femicide rates (the killing of females by males just because they are female) in the world. Sexual violence occurs there with widespread impunity, which reinforces inequality by further entrenching culturally accepted forms of discrimination; it is one of the main barriers to social justice (Torres, 2008). In seeking to understand femicide, it is important to understand the systemic impunity and structures of power in Guatemala and how femicide continues to be practised in the context of post-conflict violence (Carey \& Torres, 2010; Godoy-Paiz, 2012; Sanford, 2008). Moreover, the political concept of feminicide, as Sanford (2008, p. 113) asserts, implicates not only the perpetrators but also the state and judicial structures for not protecting the rights of women.

Another risk, and a strong perception of insecurity, originates from the generalised practice and culture of extortion, or the fear of extortion, by the various gangs or other criminal urban actors. Extortion is a sign of a weak state; it is a fundamental part of the parallel criminal economy existing in Guatemala. One young woman 
in 5 de Noviembre talked about how insecure she feels in the community because of this practice: "My old neighbour's husband was killed because he didn't pay an extortion demand; then she left because she was afraid they would kill her family." Extortion is also an expression of the authority that organised crime can exercise over a community. The main targets of extortion are small businesses and various modes of transportation (red buses, taxis), but the chance of being a victim of extortion is always present (O'Neill, 2019). The practice of extortion is so embedded in this parallel illegal economy that some residents mentioned that it has also become a practice recently adopted by members within the same family.

The informants' strong perceptions of insecurity and fear are also largely shaped by mass media's portrayals of violence. Most of the interviewees highlighted how insecure and dangerous the city was by referencing their first-hand experiences, but they especially mentioned that their perception of fear was constructed and influenced by the news (González-Izás, 2017, p. 123; Huhn et al., 2006). Television news plays a fundamental role in exacerbating a constant climate of fear. Shootings, homicides, kidnappings, and assaults dominate stories in the media and shape the image of "no-go spaces," deepening the stigmatisation of certain areas like zone 18 , considered to be a "red zone." Hence, news stories feed and reinforce the geographies of fear and insecurity. Moreover, the fear of crime and sensationalism, as Huhn and Warnecke-Berger $(2017$, p. 3) note, are part of a political agenda that justifies increased social and geographic segregation, feeding the needs of the private security industry and validating the so-called mano dura ("heavy hand") policies in a "struggle for power and social recognition, privileging some social groups while excluding others."

The worst consequences of people feeling so insecure and fearful are extreme isolation and seclusion within their houses (with some differences related to age and gender). The problem, as expressed by a middleaged man in Arzú, is as follows: "When the settlement started, we were organised; we took turns at night patrolling the streets. But that was 21 years ago. Now, with the gangs, the younger generations are afraid." Fear and insecurity divide and fracture community organisation and weaken solidarity and trust among residents. As research on other Central American cities has shown, the close interrelationship between social exclusion and violence limits the capacity of communities to organise (Muggah, 2014; Pérez-Sáinz, 2015).

The residents' main strategies for coping with the omnipresent threats of violence involve survival efforts, limiting their lives to a reduced ratio of movement and activities with severe restrictions on their personal freedom. Based on their perceptions of risk, they build mental maps of the most dangerous areas and avoid those streets (Mcllwaine \& Moser, 2007). The "normalisation" of violence and the stigmatisation (through the mass media) of certain areas of the city, considered "red zones" (like zone 18), has had negative consequences for residents of those communities, reinforcing their exclusion (O'Neill, 2019).

As Sanford (2008, p. 108) claims, it is "against this backdrop of genocide and impunity that Guatemalans today find themselves living in an extremely violent country." The myriad types of violence and the consequences of such violence in both communities can partly be explained as legacies of a violent post-conflict society, where processes of exclusions, inequalities, and vulnerabilities are constantly produced and reproduced, especially in the more marginal urban spaces. Such communities are caught in the "cross-fire," subject to manipulation by the state, various drug groups, and a highly corrupt elite political sector in a vicious cycle of exclusion, violence, and endemic poverty. The negative impact of the interrelationship between multiple types of violence-whether economic, social, institutional, gender-based, or structural-and the generalised perception of insecurity and fear in these marginal urban spaces has negative consequences for the lives of the residents in both communities.

\section{Occupying the Ravines: Environmental Risks, Structural Violence, and the Injustice of Spatiality}

The lack of state policies to support popular housing and urban-rural migration, to mitigate poverty and marginalisation, has led to the occupation and consolidation of hazardous and risk-prone areas by low-income populations in Guatemala City. Through the lens of structural violence (Farmer, 2003, p. 50; Galtung, 1969), I will now address these people's perceptions of environmental risk. This approach makes it possible to examine the root causes of spatial injustice and assess how inequalities are embodied in the interrelated risks and suffering that residents are exposed to because of their vulnerable condition.

Two main types of environmental risks have been identified in both communities. The first type includes natural hazards, such as tropical storms, hurricanes, and heavy rainfall during the rainy season (from May to October), as well as earthquakes and volcanic eruptions (Perpendicular, 2017a, 2017b). The second type includes everyday hazards (e.g., poor sanitation, air pollution, water and garbage pollution, precarious housing; see Pelling, 2003, p. 16). The following is a list of the major risks and insecurities related to natural and everyday hazards in both Arzú and 5 de Noviembre, according to community interviews:

- Landslides;

- Flooding;

- Sewers and wastewater discharged into rivers;

- Garbage pollution;

- River pollution;

- Rats and cockroaches attracted by the garbage;

- Diseases and allergies caused by pollution; 
- Lack of infrastructure (footpaths or stairs), dangerous to descend the hill, muddy in the rainy season and dry and slippery during the wet season.

Some people are more at risk than others depending on where they live in the ravine and the condition of their houses, which affects them in different ways. Ravine dwellers located next to the river have a greater perception of risk because they are more vulnerable to flooding. A single mother from 5 de Noviembre described her fears during the rainy season:

They say I am not at risk, but I think I am. Especially when I hear the noise of the pouring rain, because I know, with time, the soil might start to loosen, since this land was a garbage dump before we came here. Now it looks nice because we have improved the conditions, but that ditch over there fills up with water every time it is pouring. I am afraid that this house they built for me will get flooded.

The residents next to the river are also closer to the garbage dump and more exposed to pollution and other hygienic problems (e.g., rats, cockroaches). Many interviewees mentioned rats, one of the most distinct symbols for violence. The flooding of the river is also linked to the accumulation of garbage in both communities. A resident of 5 de Noviembre mentioned that one of the greatest risks for them was "pollution from the river during the dry season, since the river gets flooded and there are lots of rats" (see Figure 6).
Another serious environmental hazard in Guatemala City is the direct discharge of untreated sewage into the rivers. Both the garbage and the sewage create a highly polluted environment in both communities and constitute the main source of infection for diarrhoea and skin and respiratory diseases, especially common during the rainy season (Ministry of Environment and Natural Resources, 2017). The location of these communities in the ravines makes them even more vulnerable because those spaces serve as a "natural drainage" system for the city: rainwater as well as domestic and industrial sewage (Gellert, 1996). For example, all the wastewater from Alameda Norte Boulevard is directly discharged into the river running through the 5 de Noviembre community, producing a foul smell in the houses next to the wastewater and causing pollution.

Potable water distribution and access to electricity are also irregular, depending on the family's income and their location in the ravine. Since many residents have precarious jobs or are unemployed (Perpendicular, 2017a, 2017b), the strategy for accessing free electricity is to install so-called diablitos. One male resident explained that they are called diablitos ("small devils") because "the truth is we are stealing the electricity... we are not paying for it." These illegal connections are the source of other risks: They can trigger accidents because they overload the system and can cause fires (Perpendicular, 2017a, p. 6). Diablitos exemplify how the state allows certain illegal practices, which then exempts it from the responsibility of providing those services (Nygren, 2018, p. 151).

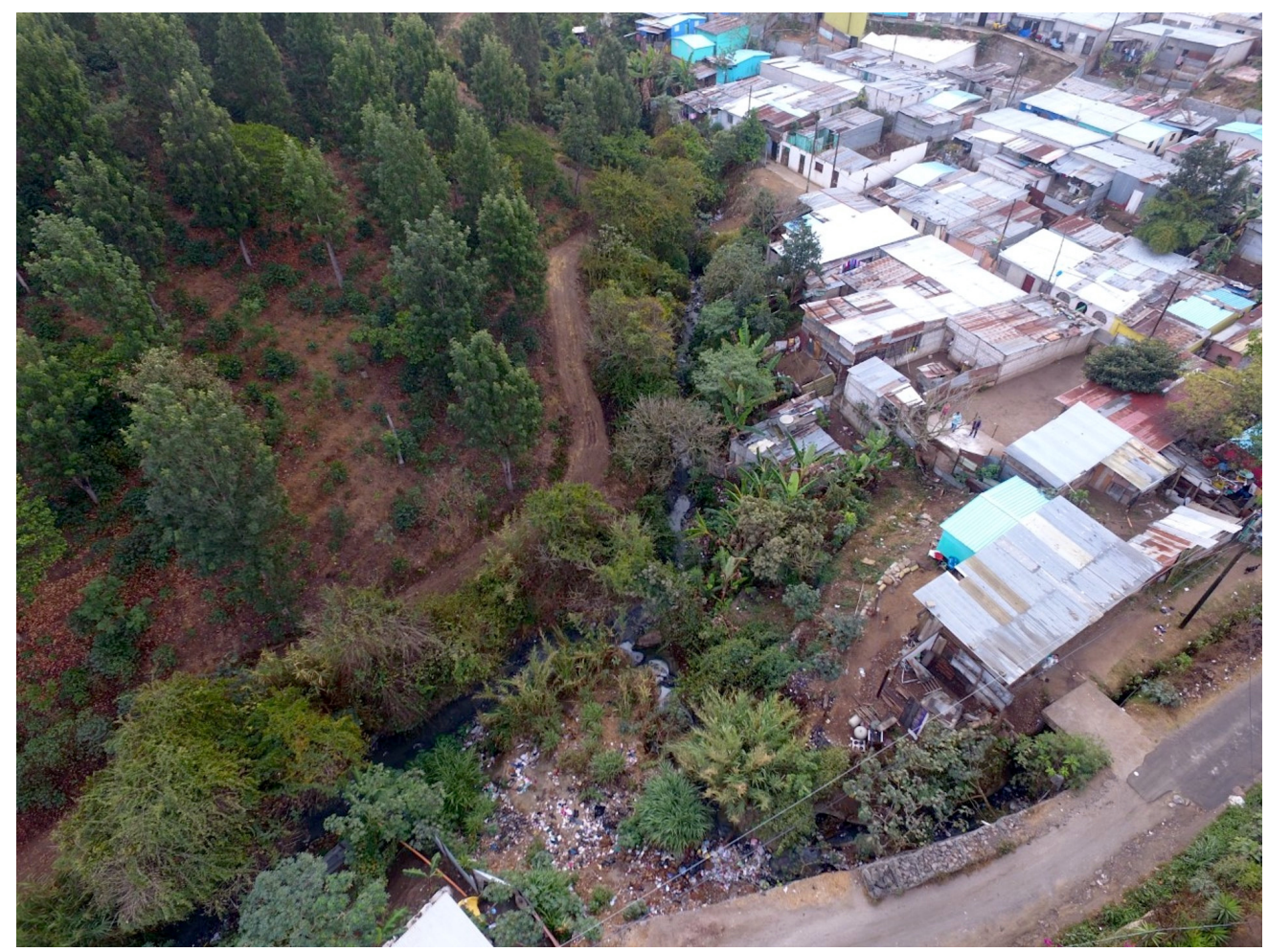

Figure 6. View of the garbage dump in the ravine in 5 de Noviembre, courtesy of Perpendicular. 
The installation of basic services and infrastructure improves over time thanks to community organisation: People rely on their own efforts and labour combined with a certain amount of aid gradually coming from the municipality, the state, and TECHO. For example, after more than 20 years of occupying the ravine, more than half the residents of Arzú now have access to a very precarious system of potable water, electricity, and housing (Perpendicular, 2017a, 2017b). Some parts of Arzú have better infrastructure, like cement sidewalks and stairs, which reduces risks and provides security for residents (see Figure 7).

One important measure for reducing risks and preventing a major disaster due to landslides is the construction of retaining walls. Many of them have been built by Unity for Popular Housing (UDEVIPO) and/or TECHO. The retaining walls are quite important for security reasons, but also because they are required before residents can be eligible for a land title if the lot is in a high-risk area (Gellert, 1996, p. 39). Residents feel quite secure when they have a retaining wall in front of their houses, even if it is a false sense of security in the case of a major earthquake or any of the other extreme environmental natural hazards so common in Guatemala.

By analysing the production of space in the ravines and improvements over time, it is possible to decentre official logics of urban spaces, as proposed by Caldeira. Residents engage in activities formerly considered illegal, gradually making their homes and the neighbourhood part of the legal system through communal strug- gles (e.g., access to land titles, certain public services). Over several decades, through their organisation and labour, they have improved their living conditions with only marginal support from the state, the municipality, and various NGOs. However, the logistics for this improvement and their efforts at mitigating the risks are embedded in a system that does little else to offer further structural solutions for the precarious situation, vulnerability, and exclusion (e.g., relocation to a safer place) faced by so many residents of the ravines. As Nygren (2018, p. 151) asserts when discussing extreme inequality and processes of urban exclusion in the case of Mexico, by keeping the residents of precarious settlements in the legal margins "authorities support their social fragility and, in this way dissipate their collective demands for justice."

\section{Conclusion}

This article has examined the spatial production of (in)justice and exclusion in two communities located in the ravines of Guatemala City, focusing on the multiple perceptions and manifestations of violence and environmental hazards and vulnerabilities. In addition to analysing the injustice of spatiality and the reproduction of inequalities and suffering, the article explored the production of peripheral urbanisation, with special attention paid to local agency. The notion of peripheral urbanisation is useful for understanding the complex dynamics and transversal logic shaping such marginal communities
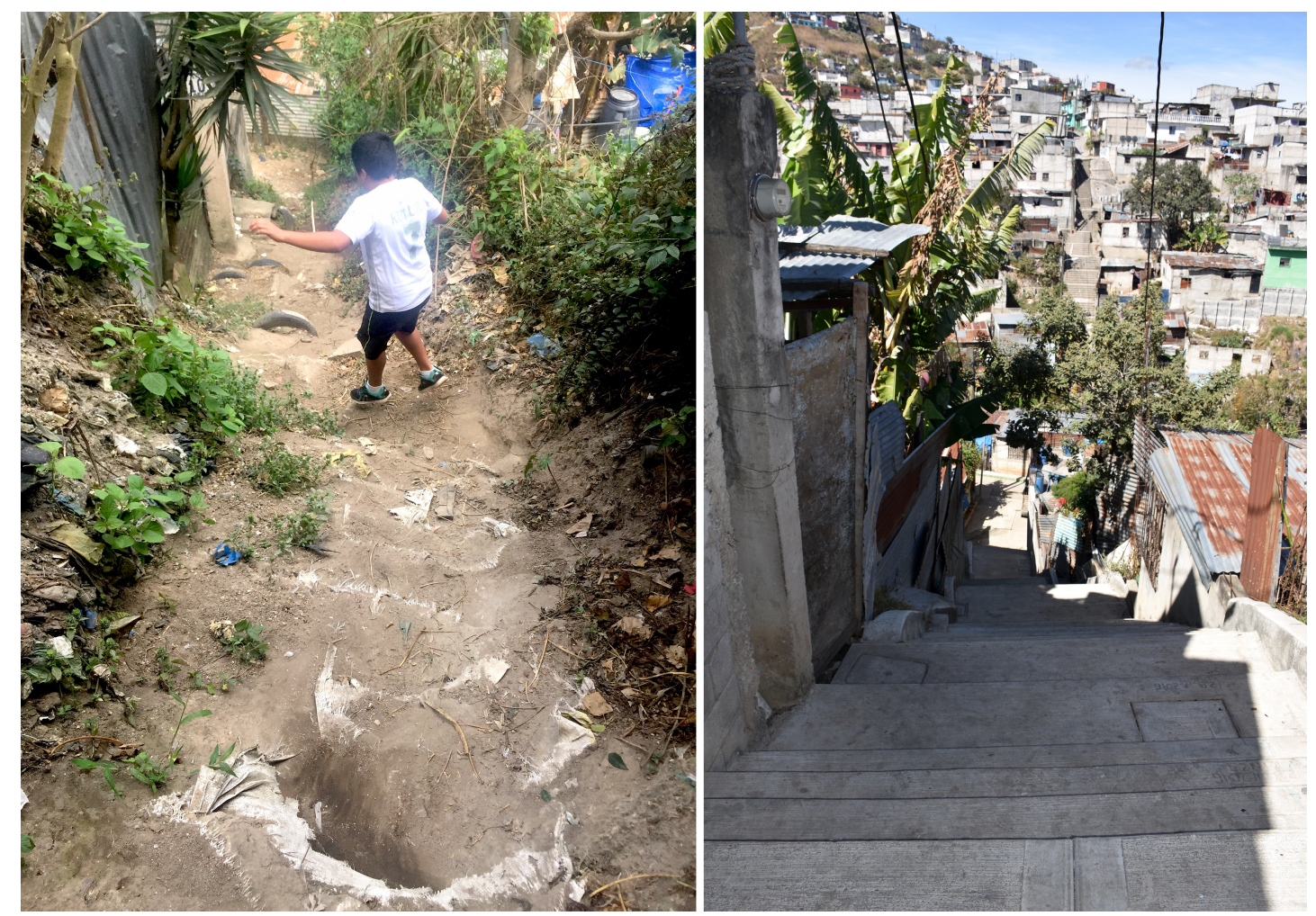

Figure 7. Contrast between the two main streets in Arzú: The cement stairs were built by active residents with the support of the municipality. 
and the importance of avoiding normative perspectives of formality and informality when studying such heterogeneous spaces.

Residents in the precarious settlements of Arzú and 5 de Noviembre, in Guatemala City, are emblematic of fragile cities and post-conflict societies characterised by a state that cannot protect and provide basic rights and security to a large number of its citizens. Residents in such precarious settlements must draw on their own resources to survive by successfully navigating overlapping forms of violence and environmental risks, thereby unsettling the dynamics of the system. Structural violence is embedded in the political, economic, and social system in Guatemala, reproducing inequality and exclusion. The state and municipality do little to tackle the real causes of poverty and problems faced by ravine dwellers; they tolerate them and provide a certain amount of infrastructure and services that only serve to reinforce the vulnerability and poverty of residents without taking any serious steps to improve the root causes of the risks they face, their vulnerability and their extreme poverty.

This article has demonstrated how residents in communities like Arzú and 5 de Noviembre are trapped in "normalised" violent, pernicious, and hazardous urban spaces, in a negative cycle that reproduces the structures of inequality and exclusion. Multiple and complex manifestations of violence fracture public space and community cohesion and are deeply disempowering. Persistent violence, or the threat of it, generates constant fear, suffering, insecurity, and vulnerability. It also generates more violence in response (Mcllwaine \& Moser, 2007). The cultural geographies of fear and the stigmatisation of "red zones" as the hotbeds of insecurity and violence in the city, all the time fed by the mass media, also reinforce the exclusion of ravine dwellers.

Focusing the analytical lens on the injustice of spatiality and the historical, socio-political, and structural processes that produce and reproduce such spatial injustice makes it easier to understand the dynamics of marginalisation and injustice in peripheral spaces in Guatemala City. Deciphering these processes helps to ground the search for spatial justice and shine a light on the urgent need for better access to democratic rights in the city, as well as the need to promote more inclusive urban planning practices. Even if spatial injustice has been historically and socially produced, it can and must be changed.

The pre-existing structural problems (e.g., poverty, inequality, corruption, impunity, insecurity) have only been exacerbated during the coronavirus pandemic, affecting especially the urban poor and deepening their economic poverty and exclusion. Concerning genderbased violence in Guatemala, research suggests a significant increase in domestic violence during governmentmandated lockdowns (lesue et al., 2021). Little empirical research has been done on the consequences of the pandemic for ravine dwellers in Guatemala City. Despite limited government funding for social programmes targeting the city's vulnerable populations, the lack of a consolidated registry of people has been an obstacle to reaching those most in need. Thus, based on the high level of informal organisation in such spaces, where residents are forced to earn their living by their own means daily, and without proper safety nets to rely on, most likely the consequences have been devastating, deepening, even more, the profound inequalities that existed before the pandemic.

\section{Acknowledgments}

I am grateful to the residents of Arzú and 5 de Noviembre, and other municipal and governmental officials and NGOs in Guatemala City, interviewed during the field research, especially Carlos Barillas. I am particularly grateful to Perpendicular (Ónice Arango and Andrea Valladares) for their key collaboration and vital support throughout the research process, and to Arango and Israel Antoni for their help during fieldwork. I would also like to thank Anja Nygren, the three anonymous referees, and the editor of this thematic issue for their insightful comments, relevant criticism, and important suggestions. This article draws on research funded by the Academy of Finland (project number 79520343) and FinCEAL Plus Research Visit Grant, UniPid.

\section{Conflict of Interests}

The author declares no conflict of interests.

\section{References}

Ayala, C. (2014). Guatemala ocho siglos de la red de localidades urbanas [Guatemala eight centuries of the urban localities' network]. Facultad de Arquitectura, USAC.

Bashir, N. (2018). Doing research in peoples' homes: Fieldwork, ethics and safety-On the practical challenges of researching and representing life on the margins. Qualitative Research, 18(6), 638-653. https://doi.org/10.1177/1468794117731808

Bourgois, P. (2015). Insecurity, the war on drugs, and crimes of the state: Symbolic violence in the Americas. In J. Auyero, P. Bourgois, \& N. Scheper-Hughes (Eds.), Violence at the urban margins (pp. 305-332). University of Oxford Press.

Briceño-León, R., \& Zubillaga, V. (2002). Violence and globalization in Latin America. Current Sociology, 50(1), 19-37. https://doi.org/10.1177/0011392102 050001003

Bruneau, T., Dammert, L., \& Skinner, E. (2011). Maras: Gang violence and security in Central America. University of Texas Press.

Caldeira, T. (2017). Peripheral urbanization: Autoconstruction, transversal logics, and politics in cities of the global south. Environment and Planning D: Society and Space, 35(1), 3-20. https://doi.org/10.1177/ 0263775816658479 
Camus, M., Bastos, J., \& López, J. (Eds.). (2015). Dinosaurio reloaded: Violencias actuales en Guatemala [Dinosaur reloaded: Current violences in Guatemala]. FLACSO.

Carey, D., Jr., \& Torres, M. G. (2010). Precursors to feminicide. Guatemalan women in a vortex of violence. Latin American Research Review, 45(3), 142-164. https://www.muse.jhu.edu/article/406422

Díaz, A., Grant, E., del Cid Vargas, P., \& Velásquez, V. (2000). El Mezquital: A community's struggle for development. Environment and Urbanization, 12(1), 87-106. https://doi.org/10.1177/095624780001200 107

Dikeç, M. (2001). Justice and the spatial imagination. Environment and Planning A: Economy and Space, 33(10), 1785-1805. https://doi.org/10.1068/a3467

Farmer, P. (2003). Pathologies of power: Health, human rights, and the new war on the poor. University of California Press.

Galtung, J. (1969). Violence, peace, and peace research. Journal of Peace Research, 6(3), 167-191. https:// doi.org/10.1177/002234336900600301

Gellert, G. (1996). Comunidades vulnerables a desastres en el área metropolitana de Guatemala [Communities vulnerable to disasters in the metropolitan area of Guatemala]. Desastres y Sociedad, 7(4), 79-94. http://desastres.medicina.usac.edu.gt/ documentos/docgt/pdf/spa/doc0018/doc0018.htm

Godoy-Paiz, P. (2012). Not just "another woman": Femicide and representation in Guatemala. Journal of Latin American and Caribbean Anthropology, 17(1), 88-109.

Goldstein, D. (2014). Qualitative research in dangerous places: Becoming and "ethnographer" of violence and personal safety. SSRC. http://webarchive. ssrc.org/working-papers/DSD_ResearchSecurity_ 01_Goldstein.pdf

González-Izás, M. (2017). El fenómeno de la violencia urbana [The phenomenon of urban violence]. FLACSO, USAID.

Grandin, G. (2000). The blood of Guatemala: A history of race and nation. Duke University Press.

Huhn, S., Oettler, A., \& Peetz, P. (2006). Construyendo inseguridades. Aproximaciones a la violencia en Centroamérica desde el análisis del discurso [Building insecurities. Approaches to violence in Central America from the analysis of discourse]. German Institute of Global and Area Studies. http://hdl.handle.net/ $10419 / 47862$

Huhn, S., \& Warnecke-Berger, H. (Eds.). (2017). Politics and history of violence and crime in Central America. Palgrave Macmillan.

Hume, M. (2004). "It's as if you don't know, because you don't do anything about it": Gender and violence in El Salvador. Environment and Urbanization, 16(2), 63-72. https://doi.org/10.1177/095624780401600 223

lesue, L., Casanova, F. O., \& Piquero, A. R. (2021). Domes- tic violence during a global pandemic: Lockdown policies and their impacts across Guatemala. Journal of Contemporary Criminal Justice, 37(4), 589-614. https://doi.org/10.1177/10439862211044867

Jütersonke, O., Muggah, R., \& Rodgers, D. (2009). Gangs, urban violence, and security interventions in Central America. Security Dialogue, 40(4/5), 373-397. https://doi.org/10.1177/0967010609343298

Koonings, K., \& Kruijt, D. (Eds.). (2007). Fractured cities: Social exclusion, urban violence and contested spaces in Latin America. Zed Books.

Koonings, K., \& Kruijt, D. (Eds.). (2009). Megacities: The politics of urban exclusion and violence in the global South. Zed Books.

Koonings, K., \& Kruijt, D. (Eds.). (2015). Violence and resilience in Latin American Cities. Zed Books.

Kurtenbach, S. (2013). The "happy outcomes" may not come at all-Postwar violence in Central America. Civil Wars, 15(1), 105-122. https://doi.org/10.1080/ 13698249.2013.850884

Levenson, D. (2013). Adiós niño: The gangs of Guatemala City and the politics of death. Duke University Press.

Mazariegos, E., Villatoro, J., \& Monterroso, R. (2014). Análisis estratégico de potencialidad y economía territorial de los barrancos del municipio de Guatemala [Strategic analysis of the potential and territorial economy of ravines in the Municipality of Guatemala]. USAC.

Mcllwaine, C., \& Moser, C. (2007). Living in fear: How the urban poor perceive violence, fear and insecurity. In K. Koonings \& D. Kruijt (Eds.), Fractured cities: Social exclusion, urban violence and contested spaces in Latin America (pp. 117-137). Zed Books.

Miles, S., Green, R., \& Svekla, W. (2012). Disaster risk reduction capacity assessment for precarious settlements in Guatemala City. Disasters, 36(3), 365-381. https://doi.org/10.1111/j.1467-7717.2011.01267.x

Ministry of Environment and Natural Resources. (2017). Informe ambiental del estado 2016: Guatemala [State environmental report 2016: Guatemala]. https://www.marn.gob.gt/Multimedios/8879.pdf

Montero, W., \& Peraldo, G. (2004). Current knowledge on the Central America historical seismicity: An analysis of recent catalogues. Annals of Geophysics, 47(2/3), 477-484.

Morán, A. (2011). Segregación, vulnerabilidad y exclusión social en la ciudad de Guatemala. Una visión de los asentamientos precarios [Segregation, vulnerability and exclusion in Guatemala City. An insight into slums]. CEUR-USAC.

Moser, C. (2004). Urban violence and insecurity: An introductory roadmap. Environment and Urbanization, 16(2), 3-16. https://doi.org/10.1177/09562478040 1600220

Moser, C., \& Mcllwaine, C. (2004). Encounters with violence in Latin America: Urban poor perceptions from Colombia and Guatemala. Routledge.

Moser, C., \& Mcllwaine, C. (2014). New frontiers in 
twenty-first century urban conflict and violence. Environment and Urbanization, 26(2), 331-344. https:// doi.org/10.1177/0956247814546283

Muggah, R. (2014). Deconstructing the fragile city: Exploring insecurity, violence and resilience. Environment and Urbanization, 26(2), 345-358. https://doi. org/10.1177/0956247814533627

Muggah, R., \& Aguirre, K. (2018). Citizen security in Latin America: Facts and figures (Strategic Paper No. 33). Igarapé Institute. https://igarape.org.br/wpcontent/uploads/2018/04/Citizen-Security-in-LatinAmerica-Facts-and-Figures.pdf

National Institute of Statistics of Guatemala. (2018). XII Censo nacional de población y VII de vivienda [XII National population census and VII on housing]. https://www.censopoblacion.gt

Nygren, A. (2018). Inequality and interconnectivity: Urban spaces of justice in Mexico. Geoforum, 89, 145-154. http://dx.doi.org/10.1016/j.geoforum. 2017.06.015

O’Neill, K. (2019). Disenfranchised: Mapping red zones in Guatemala City. Environment and Planning $A$ : Economy and Space, 51(3), 654-669. https://doi.org/ $10.1177 / 0308518 \times 18800069$

O'Neill, K., \& Thomas, K. (Eds.). (2011). Securing the city: Neoliberalism, space and insecurity in postwar Guatemala. Duke University Press.

Pelling, M. (2003). The vulnerability of cities: Natural disasters and social resilience. Earthscan.

Pérez-Sáinz, J. P. (Ed.). (2015). Exclusión social y violencias en territorios urbanos centroamericanos [Social exclusion and violence in Central American urban territories]. FLACSO. https://flacso.or.cr/ publicaciones/exclusion-social-y-violencias-enterritorios-urbanos-centroamericanos

Pérez-Sáinz, J. P. (Ed.). (2018). Vidas sitiadas: Jóvenes, exclusión laboral y violencia urbana en Centroamérica [Lives besieged: Youth, labor exclusion and urban violence in Central America]. FLACSO. https://flacso.or.cr/publicaciones/vidas-sitiadas-2

Perpendicular. (2017a). Mapeo digital: Informe final, 5 de Noviembre, zona 18 [Digital mapping: Final report on 5 de Noviembre, zona 18]. Unpublished document.

Perpendicular. (2017b). Mapeo digital: Informe final, Comunidad Arzú, zona 18 [Digital mapping: Final report on Arzú community, zone 18]. Unpublished document.

Platas, F., Morán, A., Aragón, J., Olayo, L., Osnaya, S., Muñiz, S., \& Zarur, J. (2016). Vulnerabilidad y riesgo urbano: Aportes desde la experiencia de Guatemala y
México [Vulnerability and urban risks: Contributions from Guatemala and Mexico]. CEUR-USAC.

Roberts, B. (2010). Moving on and moving back: Rethinking inequality and migration in the Latin American city. Journal of Latin American Studies, 42(3), 587-614. http://www.jstor.org/stable/40984896

Rodgers, D. (2009). Slum wars of the 21st century: Gangs, mano dura and the new urban geography of conflict in Central America. Development and Change, 40(5), 949-976. https://doi.org/10.1111/j.1467-7660. 2009.01590.x

Sanford, V. (2008). From genocide to feminicide: Impunity and human rights in twenty-first century Guatemala. Journal of Human Rights, 7(2), 104-122. https://doi.org/10.1080/14754830802070192

Scheper-Hughes, N., \& Bourgois, P. (2004). Introduction: Making sense of violence. In N. Scheper-Hughes \& P. Bourgois (Eds.), Violence in war and peace (pp. 1-31). Blackwell.

Secretariat for the Planning and Programming of the Presidency. (2015). Proyecto de cartografía metropolitana [Metropolitan cartography project]. Gobierno de Guatemala, Banco Mundial.

Snodgrass-Godoy, A. (1999). "Our right is the right to be killed": Making rights real on the streets of Guatemala City. Childhood, 6(4), 423-442. https:// doi.org/10.1177/0907568299006004003

Soja, E. (2009). The city and spatial justice. Justice Spatiale/Spatial Justice, 1(9). shorturl.at/fjuyV

Soja, E. (2010). Seeking spatial justice. University of Minnesota Press.

Torres, M. G. (2008). Imagining social justice amidst Guatemala's post-conflict violence. Studies in Social Justice, 2(1). https://doi.org/10.26522/ssj.v2i1.964

Torres-Rivas, E. (2007). La piel de Centroamérica: Una vision epidérmica de setenta y cinco años de su historia [The skin of Central America: An epidermal vision of 75 years of its history]. FLACSO.

Winton, A. (2004). Young people's views on how to tackle gang violence in "post-conflict" Guatemala. Environment and Urbanization, 16(2), 83-99. https://doi. org/10.1177/095624780401600225

Winton, A. (2005). Youth, gangs, and violence: Analysing the social and spatial mobility of young people in Guatemala City. Children's Geographies, 3(2), 167-184. https://doi.org/10.1080/1473328050016 1537

Wolf, S. (2017). Mano dura: The politics of gang control in El Salvador. University of Texas Press.

\section{About the Author}

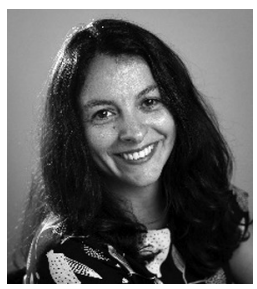

Florencia Quesada is a university lecturer in Latin American studies at the Department of Cultures, University of Helsinki. She is affiliated as a researcher with the Helsinki Institute of Sustainability Center (HELSUS) and the Helsinki Inequality Initiative (INEQ). Her research interests include urban cultural history, sustainable tourism, and urban segregation. Quesada has also been part of the research project Fragile Cities in the Global South, which focuses on societal security, environmental safety, and urban justice in Mexico, Guatemala, Colombia, and India. 